\title{
"Improvement of operational management of innovative production processes based on the implementation of MES"
}

\begin{tabular}{|c|c|}
\hline \multirow{5}{*}{ AUTHORS } & Victor M. Balashov (D https://orcid.org/0000-0003-4642-5701 \\
\hline & Aleksandr M. Batkovskiy (D https://orcid.org/0000-0002-5145-5748 \\
\hline & Elena G. Semenova (D https://orcid.org/0000-0001-8312-4903 \\
\hline & Valeriy Ya. Trofimets (D https://orcid.org/0000-0002-6873-6642 \\
\hline & Alena V. Fomina id https://orcid.org/0000-0002-5853-0309 \\
\hline ARTICLE INFO & $\begin{array}{l}\text { Victor M. Balashov, Aleksandr M. Batkovskiy, Elena G. Semenova, Valeriy Ya. } \\
\text { Trofimets and Alena V. Fomina (2018). Improvement of operational management } \\
\text { of innovative production processes based on the implementation of MES. } \\
\text { Problems and Perspectives in Management, 16(4), 1-12. } \\
\text { doi:10.21511/ppm.16(4).2018.01 }\end{array}$ \\
\hline DOI & http://dx.doi.org/10.21511/ppm.16(4).2018.01 \\
\hline RELEASED ON & Monday, 08 October 2018 \\
\hline RECEIVED ON & Tuesday, 26 June 2018 \\
\hline \multirow[t]{2}{*}{ ACCEPTED ON } & Wednesday, 01 August 2018 \\
\hline & $(c c) \overline{E Y-N C}$ \\
\hline LICENSE & $\begin{array}{l}\text { This work is licensed under a Creative Commons Attribution-NonCommercial } 4.0 \\
\text { International License }\end{array}$ \\
\hline JOURNAL & "Problems and Perspectives in Management" \\
\hline ISSN PRINT & $1727-7051$ \\
\hline ISSN ONLINE & $1810-5467$ \\
\hline PUBLISHER & LLC "Consulting Publishing Company "Business Perspectives" \\
\hline FOUNDER & LLC "Consulting Publishing Company "Business Perspectives" \\
\hline
\end{tabular}

NUMBER OF REFERENCES

44
NUMBER OF FIGURES

4
ニニ:-

NUMBER OF TABLES

5

(C) The author(s) 2023. This publication is an open access article. 


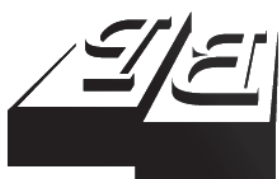

BUSINESS PERSPECTIVES

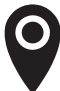

LLC “CPC "Business Perspectives" Hryhorii Skovoroda lane, 10, Sumy, 40022, Ukraine

www.businessperspectives.org

Received on: $26^{\text {th }}$ of June, 2018 Accepted on: $1^{\text {st }}$ of August, 2018

(C) Victor M. Balashov, Aleksandr M. Batkovskiy, Elena G. Semenova, Valeriy Ya. Trofimets, Alena V. Fomina, 2018

Victor M. Balashov, Dr. Sci. (Engineering), Professor, JSC "Scientific and Production Enterpise "Radar MMS”, Russian Federation.

Aleksandr M. Batkovskiy, Dr. Sci. (Economics), Senior Researcher, JSC "Central Research Institute of Economy, Management and Information Systems "Electronics", Russian Federation.

Elena G. Semenova, Dr. Sci. (Engineering), Saint-Petersburg State University of Aerospace Instrumentation, Russian Federation.

Valeriy Ya. Trofimets, Dr. Sci. (Engineering), Professor, SaintPetersburg Mining University, Russian Federation.

Alena V. Fomina, Dr. Sci. (Economics), Assistant Professor, JSC "Central Research Institute of Economy Management and Information Systems "Electronics", Russian Federation.

\section{(ㄷ)(1) $(8)$}

This is an Open Access article, distributed under the terms of the Creative Commons Attribution-NonCommercial 4.0 International license, which permits re-use, distribution, and reproduction, provided the materials aren't used for commercial purposes and the original work is properly cited.

Victor M. Balashov (Russian Federation), Aleksandr M. Batkovskiy (Russian Federation), Elena G. Semenova (Russian Federation), Valeriy Ya. Trofimets (Russian Federation), Alena V. Fomina (Russian Federation)

\title{
IMPROVEMENT OF OPERATIONAL MANAGEMENT OF INNOVATIVE PRODUCTION PROCESSES BASED ON THE IMPLEMENTATION OF MES
}

\begin{abstract}
Theoretical and practical issues of improving the quality of operational management of production processes through the implementation of MES (Manufacturing Execution Systems) are considered. To assess the risk of introduction of systems of this class, a basic set of seven influencing factors is defined. The qualitative approach to risk assessment proposes using two ordinal scales, on the basis of which the matrix for estimating the probability of occurrence of risk factors and the degree of their negative impact is built. The quantitative approach to risk assessment proposes using the formula for calculating the integral risk factor. The choice of the matrix organizational structure of management is justified in the realization of projects for implementation of MES at the enterprises with the innovative nature of production. Typical functional subsystems of MES implemented on the SIMATIC IT platform are identified and analyzed. Original express methods for evaluating the economic efficiency of investment projects for the introduction of MES are proposed. Practical testing of methodology is carried out through the example of evaluating the economic efficiency of the project for implementation of a MES at the enterprise with an innovative nature of production. As the results, relevant for the theory of building MES, the generalized algorithms of their functioning are proposed: the algorithm of operational planning of production processes with the use of a MES and the algorithm of the interaction of model functional modules in MES. The advantages of MES of new generation, i.e. management systems of combined production, are analyzed.
\end{abstract}

\section{Keywords}

\section{JEL Classification}

\section{INTRODUCTION}

One of the main factors of competitive advantage and investment attractiveness of the enterprise is the used methodology of the management of business processes. One of these methodologies, which originated at industrial enterprises in the late $19^{\text {th }}$ century, is a methodology for operational management of production. By the mid-20th century, the functional structure was formed, typical of many modern enterprises, in which the system of operational management of production started acting as the primary receiver and the source of information for all the major services of the enterprise.

Currently, the system of operational management of production is entrusted with the task of accelerating the introduction of new products to the market, increasing production flexibility, reducing the amount of waste and inventory, decreasing downtime, and ensuring optimal quality and production efficiency across all divisions. 
The performance of all these tasks requires integrated information infrastructure that helps coordinate production globally, including in real time. Such coordination affects the specifications, equipment, technological processes, organizational procedures, quality tests, and production staff. At modern enterprises, for solving the problems of coordination, productivity and flexibility of production, starting from the shop level, information systems are introduced, which obtained the name of systems of operative control of production processes.

\section{LITERATURE REVIEW}

A large number of works are dedicated to the problems of operational management of production and discussing various aspects of this type of management.

The works by Alekhina, Voronov, and Udalov (2013), Averous and Thierry (2015), Groover (2015), Adegbite et al. (2018), Prause and Atari (2017), Orekhova and Kuzmin (2017), etc. cover a wide range of issues on the general problems of improving the efficiency of production management both in operational and in strategic terms. In these works, the emphasis is made on the assessment of the information and time nature of the control and comparative analysis of operational and strategic management of production processes at industrial enterprises. One more complex and important scientific problem, which, to date, has not been systematically and comprehensively solved, is the development of theoretical and methodological issues of operational management of production. Various approaches to the study of this problem are considered in Halevi (2014), Chiarini (2015), Nahmias and Lennon (2015), Douglas and Wykowski (2017), Heizer, Render, and Munson (2017) and other works. Some aspects of operational management in relation to risks and uncertainty are discussed in Abbas (2018), Kuzmin (2015), etc. The features of operational management based on industry-specific production are disclosed in Yegorova (2016), Gillespie (2017), etc. It should be noted that in recent years, special attention has been paid to the issues of innovative production management (Huws, 2014; Buchmann, 2015; Carayannis, Samara, \& Bakouros, 2015; Ivanilova, 2018; Benešová et al., 2018).

The works by Rao (2010), Wiendahl, Reichardt, and Nyhuis (2015), Backström, Fundin, and Johansson (2017) are devoted to the use of economic-mathematical methods and models in the operational management of production processes.
A special place among them is taken by the methods and models of operational scheduling (Eiselt \& Sandblom, 2013; Cai, 2014; Fazlollahtabar \& SaidiMehrabad, 2015). The questions of production processes automation are investigated in Kongoli (2012), Lamb (2013), Panteleev and Proshin (2015), Jash and Saha (2016), Pavlov (2017), and other works. Among them, there are notable works, in which the focus is shifted to the systems of operational control of production processes - MES (Andreev, I. Kutsevich, \& N. Kutsevich, 2015; World Outlook for Manufacturing Execution Systems, 2017). Some of them (see, for example, Boje, 2015) examine the impact of the introduction of information systems on the organizational structure of enterprise management. The architecture and functionality of particular MES are discussed in Koryagin, Sukhorukov, and Medvedev (2015), V. Chernov and I. Chernov (2016), and other works.

Despite the relatively large number of studies on the subject, it should be noted that the task of improving operational management of innovative manufacturing processes through the implementation of MES has not arrived at the necessary solutions and requires further research.

\section{MATERIALS AND METHODS}

\subsection{Risk assessment implementation of a MES}

First, prior to making the decision on introducing MES, the identification and assessment of risks were carried out. For this, one can use various methods recommended in GOST R ISO/IEC 31010-2011 (2011).

To assess the risk of introduction of MES, it is expedient to apply methods used in situations where 


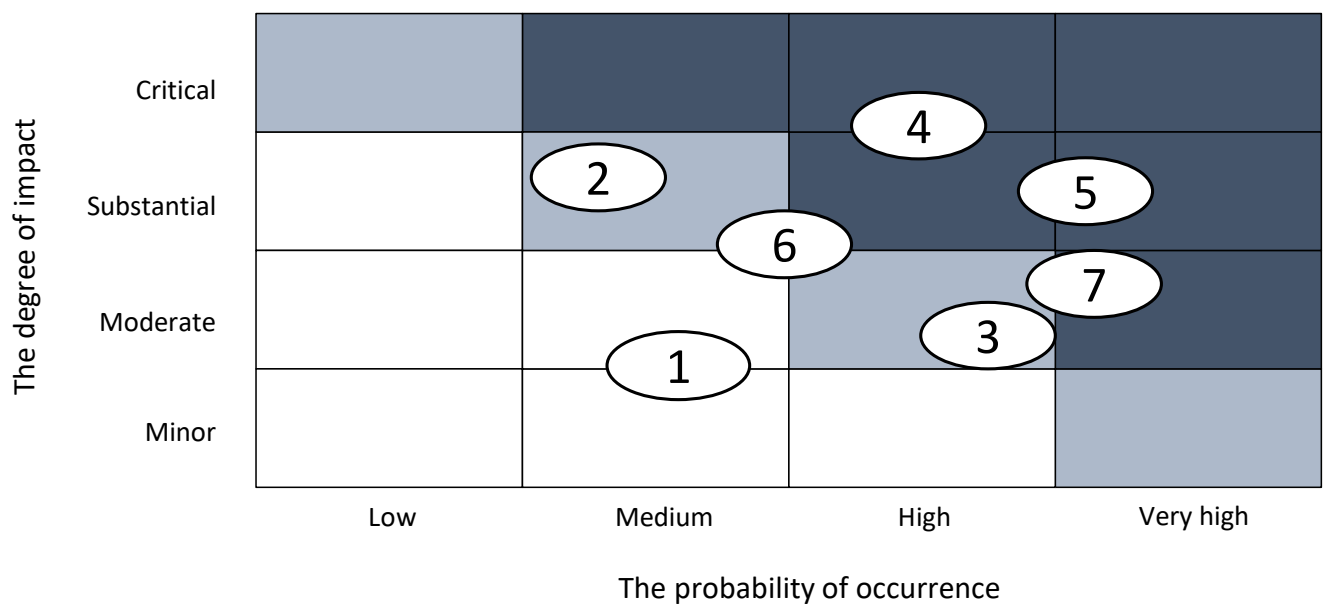

Figure 1. The risk assessment matrix of implementation of a MES

there is no possibility to accurately determine the probability of occurrence of undesirable deviations or quantify the severity of the consequences. These methods include the following: structured or semi-structured interviews, scenario analysis, the analysis of impact on business, and the analysis of the event tree in Anderson (2013), Hardy (2014), Batkovskiy et al. (2017).

To assess the risk of implementing a MES, it is proposed to use the following basic set of influencing factors, which can be adjusted depending on the characteristics of the project:

1. Fuzzy understanding of the expected outcomes from the implementation of the system.

2. Fuzzy understanding and definition of system requirements.

3. Lack of understanding of the functioning of the system of algorithms.

4. The complexity and redundancy of the system interfaces.

5. Insufficient time for implementation of the system in current production.

6. Integration of heterogeneous technological equipment, significant improvement of the existing production lines.

7. Changes in the requirements and specifications in the process of integration of the system.
For the selected factors, the expert working group compiles a matrix of estimates of the probability of their occurrence and the degree of negative impact.

The qualitative assessment of the factors proposes using the following ordinal scale: the probability of occurrence of factors: low, medium, high, very high; the negative affect of factors: minor, moderate, substantial, critical.

Figure 1 shows the matrix built by an expert working group when assessing the risks of implementation of a MES at Russian innovative companies.

In Figure 1, the squares below the main diagonal of the matrix correspond to the low risk area, the squares of the main diagonal - to the area of medium risk, the squares above the main diagonal - to the high risk area. The matrix presented in Figure 1 shows that the risk of introducing a MES at the enterprise under review is mostly moderate.

In that case, if you want to obtain a quantitative integrated assessment of the risk factor, it is proposed to use the following formula:

$$
F R_{i}=P_{i}+I_{i}-P_{i} \cdot I_{i},
$$

where $F R_{i}$ - integral evaluation of the $i$-th factor $F R_{i} \in[0 ; 1], P_{i}-$ the probability of occurrence of the $i$-th factor $P_{i} \in[0 ; 1], I_{i}$ - the degree of influence of the $i$-th factor $I_{i} \in[0 ; 1]$.

For the integral assessment of the risk factor $F R_{i}$, it is proposed to set the following ap- 


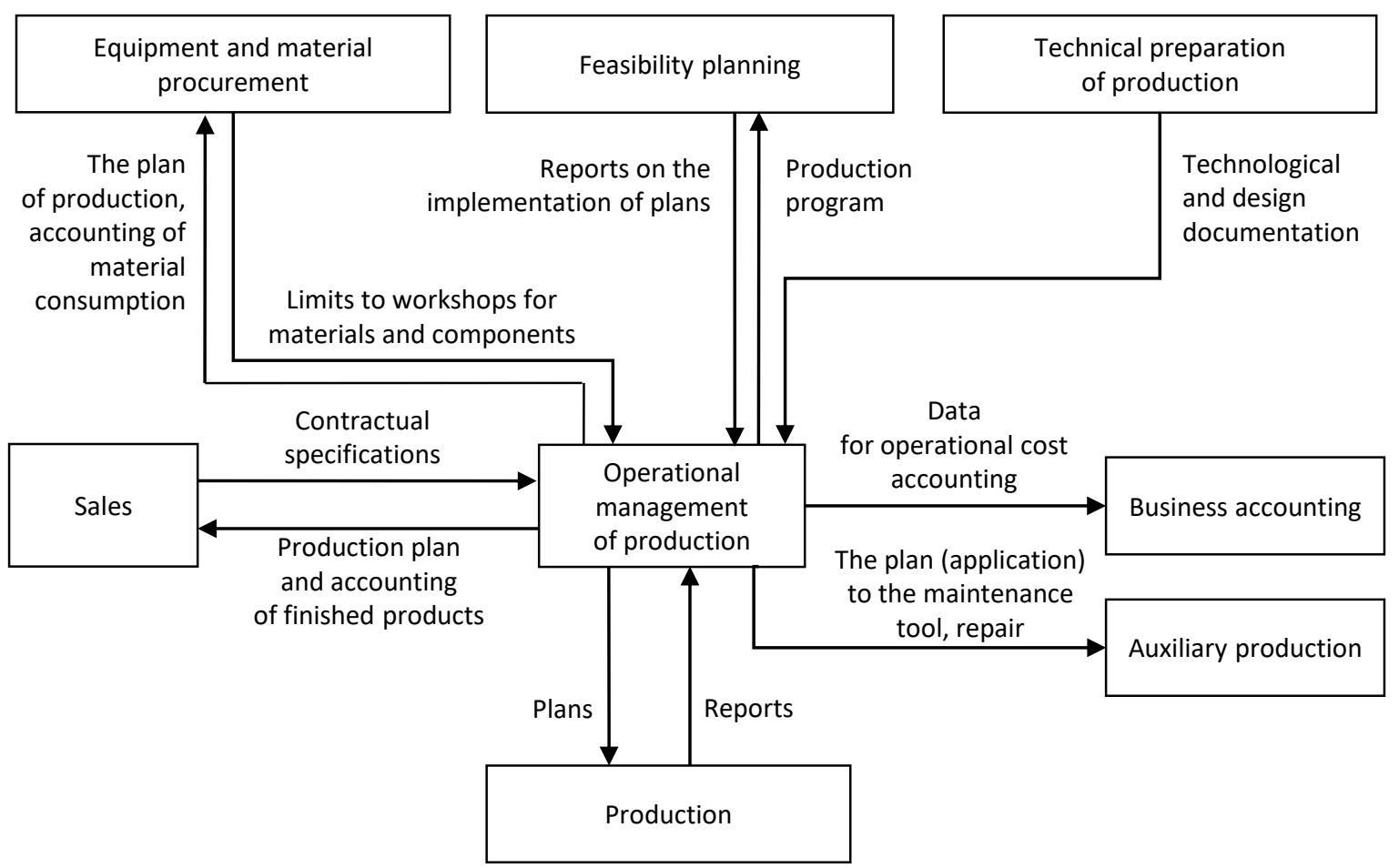

Figure 2. Information flows between the service of operating production management and other enterprise services

proximate boundaries: $F R_{i} \in[0 ; 0.3]$ - lowrisk area, $F R_{i} \in[0.3 ; 0.7]$ - medium-risk area, $F R_{i} \in[0.7 ; 1]$ - high-risk area.

These boundaries can be adjusted with a set of statistics for the ongoing projects implementation of MES systems.

\subsection{The choice of organizational structure of enterprise management}

The implementation of projects for the implementation of MES showed that these systems impact not only the processes of operational management, but also the principles of management of the whole enterprise (MESA International, 2009).

In most of the projects for the implementation of MES at the enterprises with the innovative nature of production and significant amount of research and development (R\&D), the matrix approach to the organizational structure of enterprise management proved to be the most effective. This circumstance, apparently, can be explained by the fact that the matrix structure combines the principles of both functional and process management systems that can be flexibly implemented in MES. Thus, the performers of business processes are under the operational control of the owner (manager) of the process and under the administrative authority of the head of the functional division. Such organization of business processes management is considered the most appropriate in the development of new complex products and the introduction of technological innovations.

One of the effects of implementing the matrix management model in the implementation of MES was the increase in the transparency of all business processes of the enterprise, which lies at the basis of the principle of appointing a manager responsible for each project or process, endowed with certain powers and a member of the working group of the director of the company. This model is implemented as pilot projects at a number of modern Russian enterprises with innovative nature of production. This made it possible to accurately describe business processes, thus facilitating the process of implementation of a MES, which became a some kind of a regulator and indicator of the enterprise's efficiency.

Another very important aspect of the symbiosis between the matrix management structure and the MES is the possibility of creating a single informa- 
tion space, even for units that are not subject to the coverage of a MES (see Figure 2) (Kurochkin, 2000).

The information given in Figure 2 proves the possibility of initiating a single information support for material and technical supply, technical and economic planning and technical preparation of production during the planning of production processes using a MES.

\subsection{The definition of the functional subsystems of the implemented MES}

The Manufacturing Enterprise Solutions Association (MESA) has identified eleven typical functions of MES (Muller, 2015):

- $\quad$ resource allocation and status (RAS);

- $\quad$ operational/detailed scheduling (ODS);

- dispatching production units (DPU);

- document control (DOC);
- data collection/acquisition (DCA);

- labor management (LM);

- $\quad$ quality management (QM);

- $\quad$ process management (PM);

- $\quad$ maintenance management (MM);

- $\quad$ product tracking and genealogy (PTG);

- $\quad$ performance analysis (PA).

These functions determine the overall appearance of MES, but depending on the chosen software platform and specialization of the implemented MES for their practical implementation, they can have significant characteristics.

Let us look at the functional subsystems, which were implemented in most of the projects for implementation of MES at Russian enterprises in the pharmaceutical industry. In most projects, as a software platform for building MES, the platform SIMATIC IT was used. Given the functionality of the platform and the specifics of automated business processes, functional subsystems were implemented (Table 1).

Table 1. Functional subsystems of the embedded MES based on the SIMATIC IT platform

\begin{tabular}{|c|c|c|}
\hline No & The name of the subsystem & Brief description of the subsystem \\
\hline 1 & $\begin{array}{l}\text { The subsystem of operational } \\
\text { production planning }\end{array}$ & $\begin{array}{l}\text { Subsystem functions are implemented in the Product Definition Manager module. } \\
\text { This module presents detailed mathematical description of all processes associated } \\
\text { with the release of each released or planned for release drug }\end{array}$ \\
\hline 2 & $\begin{array}{l}\text { The subsystem of control of storage } \\
\text { of raw materials and components } \\
\text { needed for production }\end{array}$ & $\begin{array}{l}\text { Subsystem functions are implemented in the software and hardware complex of } \\
\text { address storage and modification codes of the materials provider with assignment } \\
\text { of an unique farm code, the same for the entire life cycle of each component within } \\
\text { the enterprise }\end{array}$ \\
\hline 3 & $\begin{array}{l}\text { Subsystem of control of material } \\
\text { flows, starting from the raw } \\
\text { materials warehouse to the finished } \\
\text { goods warehouse }\end{array}$ & $\begin{array}{l}\text { Subsystem functions are implemented in the module of material management } \\
\text { Material Manager, which allows to obtain data from each plot (up to } 35 \text { points of } \\
\text { hardware control) at the stages of moving the raw materials with the help of pharma } \\
\text { code scanners or RFID tags readers }\end{array}$ \\
\hline 4 & $\begin{array}{l}\text { The subsystem of production plans } \\
\text { processing for maximum loading of } \\
\text { process equipment }\end{array}$ & $\begin{array}{l}\text { The formulation of plans is based on the interaction of the module Production } \\
\text { Modeler with the modules Product Definition Manager, Personnel Manager, } \\
\text { Production Order Manager and Material Manager }\end{array}$ \\
\hline 5 & $\begin{array}{l}\text { Subsystem of status monitoring of } \\
\text { the process equipment, cleaning } \\
\text { technology management and } \\
\text { preparing equipment for production }\end{array}$ & $\begin{array}{l}\text { Subsystem functions are implemented in the modules of self-diagnostic, internal } \\
\text { parameters control and communicate with external systems. They allow a high } \\
\text { degree of accuracy to predict the failure of equipment to build and repair schedules } \\
\text { to minimize the stock of components and spare parts }\end{array}$ \\
\hline 6 & $\begin{array}{l}\text { Monitoring subsystem of production } \\
\text { environments and forming an } \\
\text { electronic dossier for every series of } \\
\text { manufactured products }\end{array}$ & $\begin{array}{l}\text { Subsystem functions are implemented within the Historian module. It is hardware } \\
\text { and software system that receives all information directly from the hardware } \\
\text { monitoring of the quality of production environments - air, water, gases required } \\
\text { for the technologies, as well as data from the production equipment and systems of } \\
\text { man-machine interface in case of data entry by authorized personnel in a manual } \\
\text { way }\end{array}$ \\
\hline 7 & $\begin{array}{l}\text { The subsystem of personnel } \\
\text { management, making it possible to } \\
\text { perform the technological processes }\end{array}$ & $\begin{array}{l}\text { Subsystem functions are implemented within the Personnel Manager. Account } \\
\text { database is fully synchronized with the MES and, if in the process of preparing for } \\
\text { the production of product, it turns out that the selected staff was not be trained, } \\
\text { production can be blocked }\end{array}$ \\
\hline 8 & $\begin{array}{l}\text { The control subsystem of laboratory } \\
\text { tests necessary for the resolution of } \\
\text { production warehouse quarantine } \\
\text { storage for the storage of finished } \\
\text { products and subsequent sale }\end{array}$ & $\begin{array}{l}\text { Subsystem functions are implemented within the Unilab. The information that } \\
\text { comes into the database module is processed according to certain algorithms and } \\
\text { presented to the decision maker in the form convenient for the analysis of related } \\
\text { trends and charts. In some cases, the system itself may decide the fate of the } \\
\text { series of drugs, based on the totality of the eligibility criteria and the accumulated } \\
\text { historical information }\end{array}$ \\
\hline 9 & $\begin{array}{l}\text { The subsystem of energy resources } \\
\text { spent for production }\end{array}$ & $\begin{array}{l}\text { Functions of the subsystem allows for efficient implementation of different power } \\
\text { saving modes: "production", "night mode", "sanitation of areas", "conservation of } \\
\text { zone", etc. }\end{array}$ \\
\hline
\end{tabular}


The functional subsystems presented in Table 1 contain a standard configurable set of functions for discrete and continuous production with the ability to adapt to the specific requirements of the enterprise. A standard set of functions encompasses mechanisms for interacting with both business systems and automation control systems, which allows to take into account the situations associated with the adjustment of equipment for the transition to the manufacture of a new product, and multiple restrictions on resources for an individual operation, as well as splitting the order into several parts depending on the decisions taken in the sphere of planning. The functional subsystems are an example of specific embodiment of the typical functions of MES defined by the Manufacturing Enterprise Solutions Association.

\subsection{The methodology of economic evaluation of projects for implementation of MES}

Projects implementing MES in their economic essence are investment projects, so the known indicators of estimation of economic efficiency of investment projects are fully applicable in this case: net income $N V$; net present value $N P V$; internal rate of return IRR; payback period $P P$; profitability index PI. On the basis of the analysis of indicators and assessment methods of efficiency and risks of investment projects, $N P V$ was considered as the most common in the practice of investment planning. This indicator is calculated according to the economic relations and is based on the assessment of cash flows from operating, investing and financing activities of the enterprise.

The $N P V$ indicator is calculated by the basic formula:

$$
N P V=P V-I_{0},
$$

where $P V$ - present value cash flow; $I_{0}$ - investment amount.

The value of $P V$ is determined by the following formula:

$$
\begin{aligned}
& P V=\frac{C F_{1}}{1+r}+\frac{C F_{2}}{(1+r)^{2}}+\ldots \\
& +\frac{C F_{n}}{(1+r)^{n}}=\sum_{t=1}^{n} \frac{C F_{t}}{(1+r)^{t}}
\end{aligned}
$$

where $r$ - rate of return, $n$ - number of periods of project implementation, $C F_{t}$ - net cash flows in time period $t$.

If the investment expenditures are incurred over a number of years, the formula (2) will be as follows:

$$
\begin{aligned}
& N P V=\frac{C F_{1}}{1+r}+\frac{C F_{2}}{(1+r)^{2}}+\ldots \\
& +\frac{C F_{n}}{(1+r)^{n}}=\sum_{t=1}^{n} \frac{C F_{t}}{(1+r)^{t}}-\sum_{t=1}^{n} \frac{I_{t}}{(1+r)^{t}} .
\end{aligned}
$$

In the implementation of a MES, at first glance, it is not difficult to estimate the investment costs $I_{0}$ associated with the acquisition of hardware and software. To do this, it is enough to submit a request for a technical and commercial proposal to potential integrators. As a rule, a technical and commercial proposal contains very accurate information about the cost of design, procurement and installation of the system. Similarly, the cost of technical support of the system can be calculated. Nevertheless, these costs are only part of the overall cost incurred in implementing a MES.

It is much harder to assess the costs associated with the development of the software under the required tasks of the enterprise. It should be noted that the system can be subsequently upgraded to cover new tasks, and by focusing on the decision, which is at first glance optimal at this point in time, it is possible to overestimate the potential and, in the short run, to understand that for future expansion and development of the system, it is necessary to change the whole thing, which is a very big risk. Therefore, to create an effective MES, investments in appropriate equipment are needed, with the expectation of future expansion, bearing in mind the plans of the company for at least five years or more (Ouardighi \& Kogan, 2013).

The greatest difficulty in assessing the economic efficiency of investment projects is the calculation of the net payment flow $C F_{t}$. To simplify this calculation, it is proposed not to build a complete model of the cash flows of the enterprise, but to limit the calculation of savings from the implementation of a MES. For this purpose, in the first approximation, it is possible to use such an objectively measurable indicator of the production process as a reduction in 
cycle time of production. In this case, to calculate the annual monetary savings from the implementation of a MES, the following formula is applied:

$$
T S_{t}=S t_{1} \cdot N \cdot P h,
$$

where $T S_{t}$ - the total savings from the implementation of a MES per year, conventional monetary units, $S t_{1}$ - time saved on the production of a series (batch) of products, hours, $N$ - number of series (batches) of products per year, $P h$ - the price of an hour of production, conventional monetary units.

An example of using the proposed method is discussed later in subsection 4.3 of the article.

\section{RESULTS}

\subsection{Generalized algorithms of MES functioning}

Based on the analysis of MES functioning and standard functions defined by MESA, generalized algorithms of these systems are proposed. In
Figure A1 (Appendix A), the generalized algorithm of operational planning of production processes with the use of a MES is presented.

MESs include typical functional modules. The algorithm of their interaction is shown in Figure 3. It characterizes the sequence of basic management procedures' implementation and the solution of planning and economic tasks.

A generic algorithm shows, in enlarged view, the interaction of typical MES modules-systems with reference to the main stages of operational management of production processes.

\subsection{The methodology of economic evaluation of projects for implementation of MESs}

Let us consider the example of evaluating the economic efficiency of the project for implementation of a MES at one of the Russian innovative companies in the pharmaceutical industry.

The source data for the calculation of the initial investment are shown in Table 2.

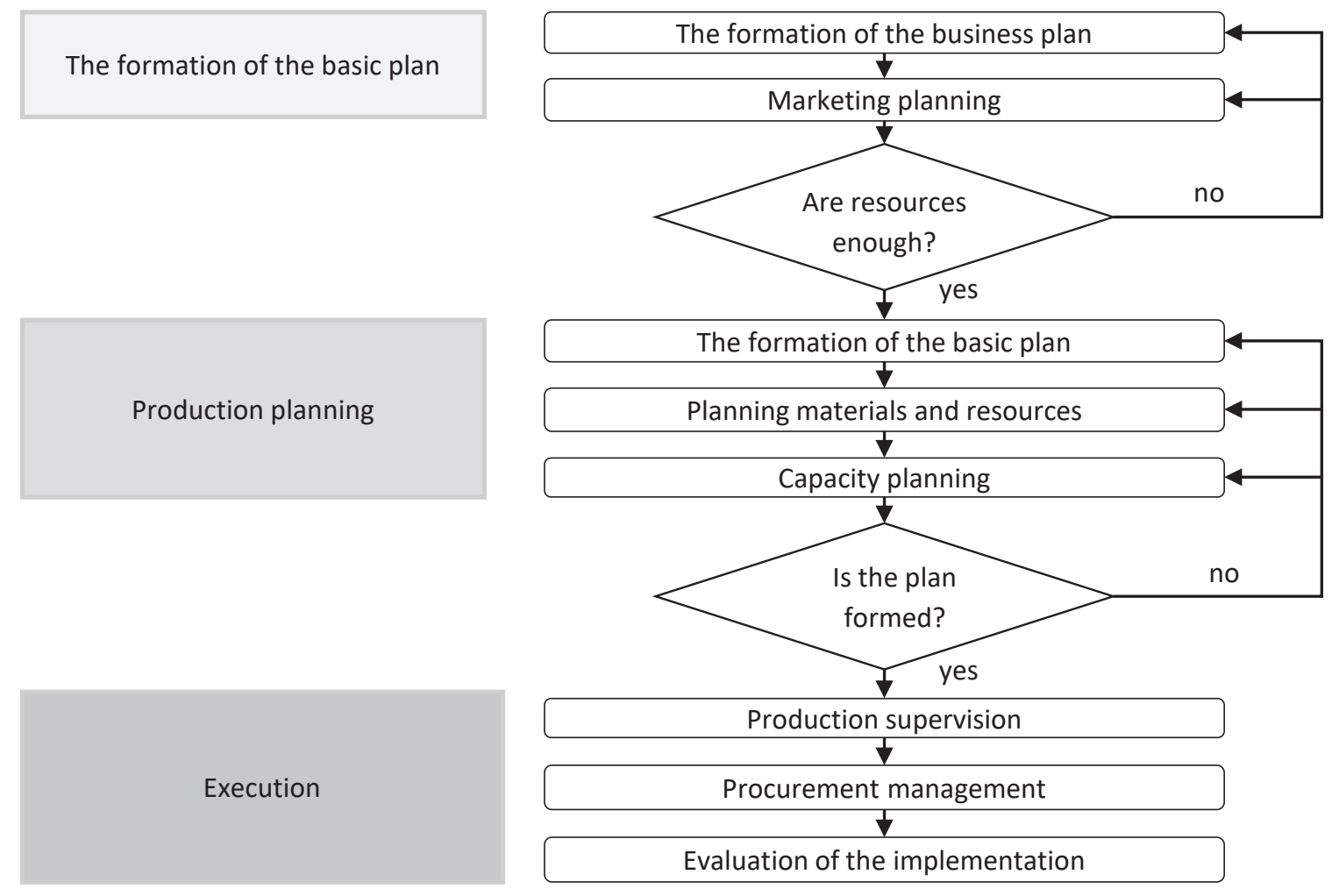

Figure 3. The algorithm of the interaction model functional modules in MES 
Table 2. Start-up costs for the project on implementation of a MES

\begin{tabular}{l|c}
\hline \multicolumn{1}{c|}{ Name of the indicator } & $\begin{array}{c}\text { Value, thousand } \\
\text { rub. }\end{array}$ \\
\hline $\begin{array}{l}\text { The cost of the description of business } \\
\text { processes }\end{array}$ & 8,550 \\
\hline $\begin{array}{l}\text { Acquisition costs (upgrade) for the } \\
\text { hardware part }\end{array}$ & 11,250 \\
\hline $\begin{array}{l}\text { The costs for the software } \\
\text { The costs for staff training }\end{array}$ & 36,000 \\
\hline Total & 6,750 \\
\hline
\end{tabular}

Thus, the initial investment $I_{0}$ will be 62,550 thousand rubles.

The source data for the calculation of the annual savings from the implementation of a MES is given in Table 3.

Table 3. Data for calculation of $T S$

\begin{tabular}{l|c}
\hline \multicolumn{1}{c|}{ Name of the indicator } & Value \\
\hline $\begin{array}{l}\text { Time saved on the production of a series } \\
\text { of (batch) production (St1) }\end{array}$ & 4.76 hours \\
$\begin{array}{l}\text { The number of series (batches) of } \\
\text { production per year (N) }\end{array}$ & 2,700 \\
\hline The price of an hour of production (Ph) & $\begin{array}{l}2.16 \\
\text { thousand rubles }\end{array}$ \\
\hline
\end{tabular}

Using the formula (5), $T S_{t}=27,756.9$ thousand rubles.

Table 4 lists the raw data to calculate the $N P V$ of the project on introduction of a MES.

Table 4. Initial data for calculation of $N P V$ of the project

\begin{tabular}{l|c}
\hline \multicolumn{1}{c}{ Name of the indicator } & Value \\
\hline Initial investments (I0) & $\begin{array}{c}62,550 \\
\text { thousand rubles }\end{array}$ \\
\hline $\begin{array}{l}\text { Annual savings from the implementation } \\
\text { of a MES (TSt) }\end{array}$ & $\begin{array}{c}27,756.9 \\
\text { thousand rubles }\end{array}$ \\
\hline $\begin{array}{l}\text { Annual maintenance costs for system } \\
\text { maintenance (It) }\end{array}$ & $\begin{array}{c}2,250 \\
\text { thousand rubles }\end{array}$ \\
\hline Rate of return (r) & $10 \%$ \\
\hline The planning horizon $(\mathrm{n})$ & 7 years \\
\hline
\end{tabular}

The calculation of NPV of the project is given in Table 5.
Table 5. Calculation of $N P V$ of the project

\begin{tabular}{c:c:c:c|c}
\hline Year & $\begin{array}{c}\text { Savings/year, } \\
\text { thousand rub. }\end{array}$ & $\begin{array}{c}\text { CFt, } \\
\text { thousand } \\
\text { rub. }\end{array}$ & $\begin{array}{c}\frac{C F_{t}}{(1+r)^{n}} \\
\text { thousand } \\
\text { rub. }\end{array}$ & $\begin{array}{c}\text { NPV, } \\
\text { thousand } \\
\text { rub. }\end{array}$ \\
\hline 0 & 0 & $-62,550$ & $-62,550$ & $-62,550$ \\
\hline 1 & 27,757 & 25,507 & 23,188 & $-41,470$ \\
\hline 2 & 27,757 & 25,507 & 21,080 & $-20,390$ \\
\hline 3 & 27,757 & 25,507 & 19,164 & 690 \\
\hline 4 & 27,757 & 25,507 & 17,422 & 21,770 \\
\hline 5 & 27,757 & 25,507 & 15,838 & 42,850 \\
\hline 6 & 27,757 & 25,507 & 14,398 & 63,931 \\
\hline 7 & 27,757 & 25,507 & 13,089 & 85,011 \\
\hline
\end{tabular}

The calculations show that the project pays for itself in three years. The average value of the effect of the introduction of $11,230.3$ thousand rubles per year. The magnitude of this effect (planned results) indicates the high economic efficiency of the considered project for the implementation of the MES.

\section{DISCUSSION}

The issues of implementation of MES, discussed in the article, are mainly related to the operational management of production processes. However, it is worth noting that in recent years, the trend has been the market introduction of the next generation of MES, which obtained the name of systems of combined production (collaborative MES or c-MES). The emergence of such systems reflects the significant progress in the management of production due to the following factors (Orekhova \& Kuzmin, 2017):

- formed common standards and methodologies for the creation of MES;

- the role of MES changes, focusing on the interactive processes of the entire enterprise;

- $\quad$ software is increasingly configured and less refined due to the fact that the solutions usually contain an extensive library of different production situations with custom components and templates;

- software requires significantly less effort to implement specific interfaces in case it is provided with the delivered custom interfaces and circuits; 
- implementation of c-MES requires professionalism in business along with knowledge in the field of information technology;

- return on investment in c-MES is significantly accelerated due to the increasing functionality and reducing cost;

- return on investment and the cost of all stages of the life cycle became more predictable due to the increase in the functionality of individual components and a reduction in the cost of programming.

The traditional MES model focuses on the provision of user information from among the operational staff (managers, dispatchers, and operators). For sharing information with other systems, the c-MES model is much more efficient. This generates an opportunity to get a much better picture of what is happening, what is particularly relevant for companies operating in innovative markets, characterized by frequent releases of new products and the short duration of the product life cycle. Such markets are primarily the markets of electronic equipment, semiconductor components, and biological products.

The errors in the management of joint production can not only lead to the reduction of sales and deliveries, missed opportunities, but also are reflected in such indicators as return on assets, operating margin, percent of late deliveries.

The increasing global competition, the development of the network economy and the increasing complexity of products (using new technologies, reducing the duration of the life cycle, etc.) create prerequisites for further expansion of the application of c-MES to support the concept of joint production. In addition to the traditional tasks of MES regarding production optimization, the basis of the c-MES model is the task of sharing accurate, detailed and timely data, systems and personnel throughout the chain of value creation.

\section{CONCLUSION}

Currently, the implementation of MES at the enterprises is widely observed. This trend is due to the fact that it becomes increasingly difficult for these enterprises to compete with companies from developing countries whose main advantage is the low cost of production. The implementation of MESs at the enterprises in developed countries allows them to increase productivity, improve product quality and reduce downtime. The implementation of MESs is usually associated with such initiatives on improving production as total quality management (TQM), "lean production", "six sigma", etc. A MES enables the user to better see what is happening at the level of departments and individual production lines, thereby facilitating the identification of the true causes of the violations and reduce the rate of production. Operative correction of violations allows to achieve productivity gains and improving product quality.

A generic algorithm shows, in enlarged view, the interaction of typical MES modules-systems with reference to the main stages of operational management of production processes. In most of the projects, for the implementation of MES at the enterprises with the innovative nature of production and significant amount of research and development $(R \& D)$, the matrix approach to organizational structure of enterprise management proved to be the most effective. One of the effects of implementing a matrix management model in the implementation of MES was the increase in the transparency of all business processes of the enterprise, which is premised on the principle of appointing a responsible manager for each project or process.

\section{ACKNOWLEDGEMENTS}

The study was supported by the Russian Foundation for Fundamental Research (RFFR), project No. 16-06-00028. 


\section{REFERENCES}

1. Abbas, S. A. (2018). Entrepreneurship and information technology businesses in economic crisis. Entrepreneurship and Sustainability Issues, 5(3), 682-692. https://doi. org/10.9770/jesi.2018.5.3(20)

2. Adegbite, O. E., Simintiras, A. C., Dwivedi, Y., \& Ifie, K. (2018). Organisational Adaptations: A Pluralistic Perspective. Springer International Publishing.

3. Alekhina, O. F., Voronov, N. A., \& Udalov, F. Ye. (2013). Operational and Strategic Production Management in Industrial Enterprises. Nizhny Novgorod: N. I. Lobachevsky State University of Nizhny Novgorod.

4. Anderson, E. J. (2013). Business Risk Management: Models and Analysis. Wiley.

5. Andreev, Ye. B., Kutsevich, I. V., \& Kutsevich, N. A. (2015). MES: The View from the Inside. RTSoft, Moscow. Retrieved July 10, 2018, from http://www.iprbookshop. $\mathrm{ru} / 71666 . \mathrm{html}$

6. Averous, J., \& Thierry, L. (2015). Advanced Scheduling Handbook for Project Managers: A Practical Navigation Guide on Large, Complex Projects. Fourth Revolution Publishing.

7. Backström, T., Fundin, A., \& Johansson, P. E. (2017). Innovative Quality Improvements in Operations: Introducing Emergent Quality Management. Springer. https://doi.org/10.1007/978-3319-55985-8

8. Batkovskiy, A. M., Semenova, E. G., Trofimets, V. Ya., Trofimets, E. N., \& Fomina, A. V. (2017). Statistical Simulation of the BreakEven Point in the Margin Analysis of the Company. Journal of Applied Economic Sciences, 2(48), 558-571. Retrieved July 10, 2018, from https://www.ceeol.com/ search/article-detail?id=532542

9. Benešová, D., Kubičková, V., Michálková, A., \& Krošláková, M. (2018). Innovation activities of gazelles in business services as a factor of sustainable growth in the Slovak Republic. Entrepreneur- ship and Sustainability Issues, 5(3), 452-466. https://doi.org/10.9770/ jesi.2018.5.3(3)

10. Boje, D. (2015). Organizational Change and Global Standardization: Solutions to Standards and Norms Overwhelming Organizations. Routledge.

11. Buchmann, J. A. (2015). Valuing the Innovation Potentials of Firms: What Theory Suggests, Practitioners Do, and both Implies for Existing Theory. Springer. Retrieved from https://www.springer.com/ gp/book/9783658092894

12. Cai, X. (2014). Optimal Stochastic Scheduling. Springer. https://doi. org/10.1007/978-1-4899-7405-1

13. Carayannis, E. G., Samara, E. T., \& Bakouros, Y. L. (2015). Innovation and Entrepreneurship: Theory, Policy and Practice. Springer. https://doi.org/10.1007/978-3319-11242-8

14. Chernov, V. F., \& Chernov, I. V. (2016). Technology of Generation of IT Systems Based on Smart-MES. Lambert Academic Publishing. Retrieved July 10, 2018, from http://inform-system.ru/ files/978-3-659-84831-5.pdf

15. Chiarini, A. (Ed.). (2015). Sustainable Operations Management: Advances in Strategy and Methodology. Springer. https://doi. org/10.1007/978-3-319-14002-5

16. Douglas, N., \& Wykowski, T. (2017). Rethinking Management: Confronting the Roots and Consequences of Current Theory and Practice. Palgrave Macmillan.

17. Eiselt, H. A., \& Sandblom, C. L. (2013). Operations Research: A Model-Based Approach. Springer. https://doi.org/10.1007/978-3642-31054-6

18. Fazlollahtabar, H., \& SaidiMehrabad, M. (2015). Autonomous Guided Vehicles: Methods and Models for Optimal Path Planning. Springer. https://doi. org/10.1007/978-3-319-14747-5

19. Gillespie, L. (Ed.) (2017). Design for Advanced Manufacturing: Technologies and Processes. McGrawHill Education.
20. GOST R ISO/IEC 31010-2011 (2011). National Standard of the Russian Federation. Risk management. The methods of risk assessment. Moscow: Autonomous Non-Commercial Organization "Monitoring and Assessment Research Centre of the control and diagnostics of technical systems".

21. Groover, P. M. (2015). Fundamentals of Modern Manufacturing, Binder Ready Version: Materials, Processes, and Systems. Wiley.

22. Halevi, G. (2014). Industrial Management - Control and Profit: A Technical Approach. Springer. https://doi.org/10.1007/978-3319-03470-6

23. Hardy, K. (2014). Enterprise Risk Management: A Guide for Government Professionals. Wiley.

24. Heizer, J., Render, B., \& Munson, Ch. (2017). Operations Management: Sustainability and Supply Chain Management (12th ed.). Pearson.

25. Huws, U. (2014). Labor in the Global Digital Economy: The Cybertariat Comes of Age. Monthly Review Press.

26. Icon Group International, Inc. (2017). World Outlook for Manufacturing Execution Systems (MES).

27. Ivanilova, S. V. (2018). Management of Innovative Projects. Moscow: Dashkov and Co.

28. Jash, C., \& Saha, D. (2016). Implementing SAP Manufacturing Execution. SAP Press.

29. Kongoli, F. (Ed.) (2012). Automation. InTeOp.

30. Koryagin, N. D., Sukhorukov, A. I., \& Medvedev, V. A. (2015). The Implementation of Modern Methodological Approaches to Information Systems Management. Moscow: Moscow State Technical University of Civil Aviation.

31. Kurochkin, A. S. (2000). Operational Management. Kiev: Interregional Academy of Personnel Management. 
32. Kuzmin, E. A. (2015). Fundamentals in Systematics of Uncertainty Management Theory. Mediterranean. Journal of Social Sciences, 6(5S2), 380-389. http:// dx.doi.org/10.5901/mjss.2015. v6n5s2p380

33. Lamb, F. (2013). Industrial Automation: Hands On. McGraw-Hill.

34. MESA International (2009). MES - Theory and Practice, Issue 1. Retrieved July 10, 2018, from http://www.mescenter.ru/images/ upload/MESbook1adv.pdf

35. Muller, S. (2015). Manufacturing Execution System (MES). Books on Demand.

36. Nahmias, S., \& Lennon, O. T. (2015). Production and Operations Analysis (Waveland Press). Retrieved July 15, 2018, from https:// www.waveland.com/browse. php?t=662

37. Orekhova, S. V., \& Kuzmin, E. A (2017). Resource Investment Model in Specifics of Developing Countries. Advances in Economics, Business and Management Research, 38, 488-494.

38. Ouardighi, F. E., \& Kogan, K. (2013). Models and Methods in Economics and Management Science. Springer. Retrieved from https://www.springer.com/us/ book/9783319006680

39. Panteleev, V. N., \& Proshin, V. M. (2015). The Fundamentals of Production Automation. Moscow: Akademiya.

40. Pavlov, Yu. A. (2017). The Foundations of Production Automation. Moscow: MISiS.
41. Prause, G., \& Atari, S. (2017). On sustainable production networks for Industry 4.0. Entrepreneurship and Sustainability Issues, 4(4), 421-431. https://doi.org/10.9770/ jesi.2017.4.4(2)

42. Rao, R. V. (2010). Advanced Modeling and Optimization of Manufacturing Processes: Inter national Research and Development. Springer. https://doi. org/10.1007/978-0-85729-015-1

43. Wiendahl, H. P., Reichardt, J., \& Nyhuis, P. (2015). Handbook Factory Planning and Design. Springer. https://doi.org/10.1007/978-3662-46391-8

44. Yegorova, E. G. (2016). Operational Management of the Process of Production of Iron Ore Sinter of Saint Petersburg. Saint Petersburg State Institute of Technology. 


\section{APPENDIX A}

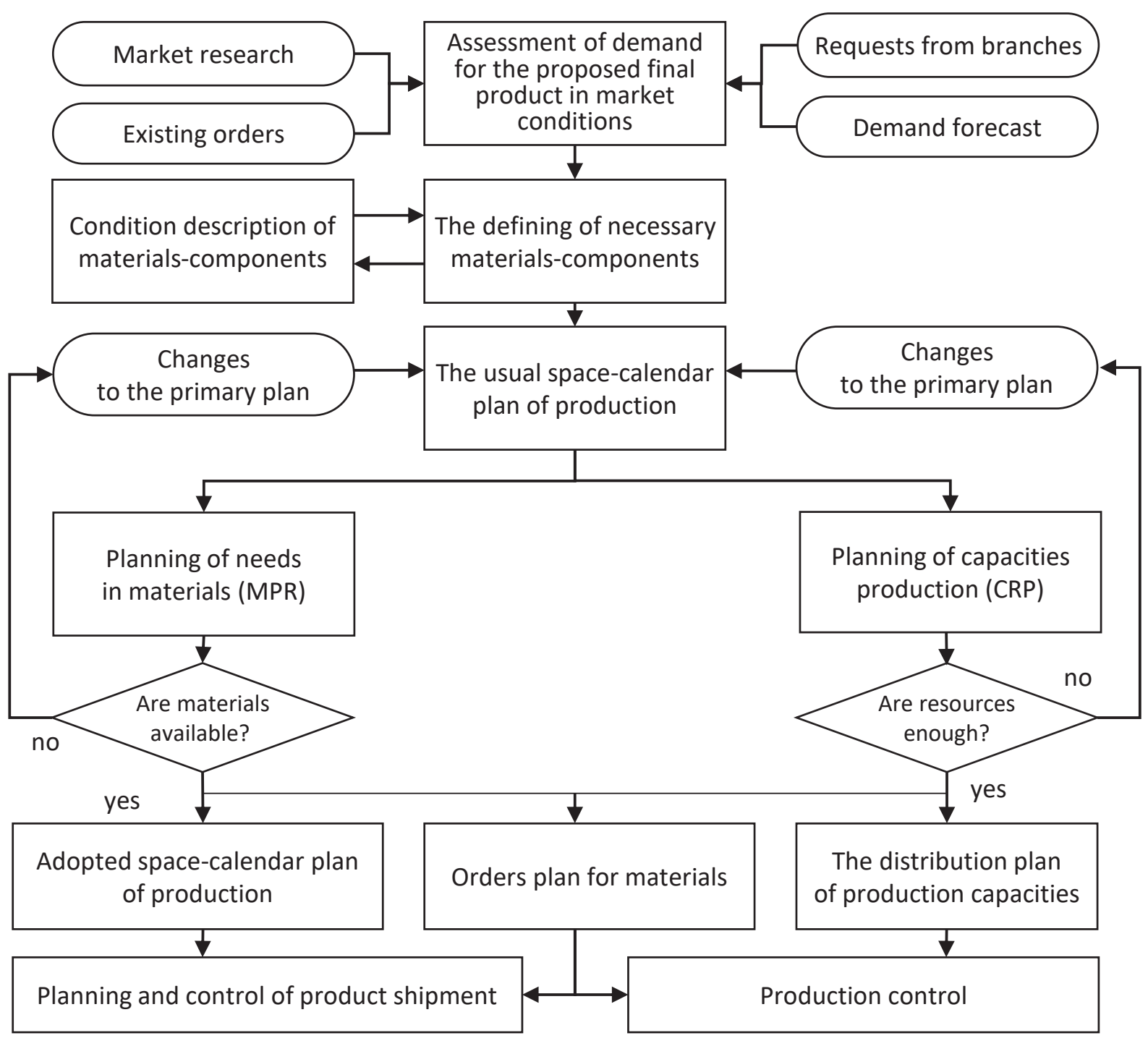

Figure A1. Algorithm of operational planning of production processes using a MES 